\title{
Negative Impacts of the Neo-liberal Policies on the Banking Sector in Bulgaria
}

\author{
Rossitsa Rangelova Pavlova', Grigor Sariiski
}

ABSTRACT

From the beginning of the 1970s until the last global financial and economic crisis in 2008-2009, neo-liberal ideas guided economic policy development. It is worth noting that the Central and Eastern European countries transformed their economies from centrally planned to a market type at the peak of the liberal policies. Bulgaria offers a particularly interesting example because the country encountered a very difficult transition from one extreme of an economic system organization to another. The paper considers the reforms in the Bulgarian banking sector during the transition period from a centrally planned to a market type economy (from 1989 onward) through the implementation of neo-liberal policies. The development of the banking sector and its transformation is analyzed throughout the two main periods: before and after the transition. The latter is divided into two sub-periods (phases) beginning with the early 1990s, followed by the financial and bank crisis in the country, the introduction of a currency board regime in 1997, and stabilization, and ending with the global crisis in 2008-2009. This article summarizes that during the transition period, a modern banking system was established to accumulate profit rather than to promote economic growth. Following a chronological order, the negative effects of the liberalization of the Bulgarian banking sector are specified: the exportation of ownership (and control) upon banking system assets, unfair asset redistribution, the emergence of the local oligarchy, the weak protection of the taxpayers and others.

KEY WORDS: neo-liberal policies, transition from centrally planned to a market type economy, financial sector, Bulgarian banking system

JEL Classification: B22, B25, E58

'Bulgarian Academy of Sciences - Economic Research Institute, Sofia, Bulgaria

\section{Introduction}

Neo-liberal ideas emerged a few decades ago. In the early 1970s, an unprecedented boom took place in economic thought. In the mid-1970s, neo-liberals received general admission (founded primarily on the ideas of Friedrich von Hayek and Nobel winner in economics Milton Friedman). Invigorated by the accelerated economic growth, the neo-liberal wave spread among industrial countries.

Correspondence concerning this article should be addressed to: Rossitsa Rangelova Pavlova, Aksakov, Street No 3, 1040 Sofia, Bulgaria.E-mail: r.rangelova@iki.bas.bg
It was reinforced also by the economic crises of the 1970s, which showed that, first, the state and governments could be weak regulators of economic life, and second, a perpetually state-managed economy could not guarantee growth. Various neo-liberal concepts conceived in London, Freiburg and the Chicago School were built on certain principles, such as the primacy of private property, low taxes, limited social policy, and a stable money supply. The uniting thesis postulates the limited state intervention in the economy and undisputed deregulation.

For the past nearly four decades, the neo-liberal ideas implemented in the Washington Consensus have guided 
development policy (Marangos, 2009). This ideology was triumphed throughout the late 1970s; however, it was afterwards evident that it bore a fundamental problem: its proclivity to generate crisis. Throughout the 1990s, the world observed several crises, for example, in Mexico (1994), East Asia (1997), Russia (1998), Brazil (1999), Argentina and Turkey (2000). Another fundamental problem that became evident later is neo-liberalism's policy failure to deliver economic growth. World growth has systematically slowed during the dominance of neo-liberalism, particularly in low- and middle-income countries. A comparative view would show that over the period 1990-1996, the growth was slower than that in 1980-1989, which, in turn, was slower than that in 1965-1980. A third fundamental problem is the tendency to worsen income distribution, be it in the industrialized world or the developing world. Thus, not only has growth slowed during the period of Washington Consensus ascendancy, but there has also been an increase in income inequality within and between the countries. Argentina's recent collapse, for instance, is a typical example of the Washington Consensus model failure. The country followed this model as closely as is ever likely to be possible in the real world of policymaking. The government liberalized the financial markets, eliminated trade barriers, privatized state assets, made its labor markets flexible, tied its currency to the dollar, and pursued monetary and fiscal austerity in the midst of a deep economic slump that bordered on a depression. Argentina's subsequent collapse has irrevocably discredited the neoliberal ideology and spotlighted the urgent need for a new development paradigm (Palley, 2002). B. Amable (2010) came to the conclusion that the neo-liberal model of economic functioning has historically been exhausted, and the current financial collapse "is not just a crisis of financial deregulation and of modern finance either. It is a crisis of the neo-liberal model of capitalism".

Currently, the failure of the neo-liberal ideas has become evident, and it is clear that there is a growing need for a new economic development paradigm. Among the numerous other publications that may be the most concentrated on this subject are the comprehensive studies of A. Kaletsky's (2010) "Capitalism 4.0: The Birth of a New Economy" and J. Stiglitz's (2010) "Freefall. Free Markets and the Sinking of the Global Economy".

Naturally, the neo-liberal model of economic organization is not uniformly applied in each country. Its application is determined by the specific economic level, social attitudes and traditions in the governance. The idea of a specific variation of management was established by the most developed market economies, leading to the belief that neo-liberal policy could be not suitable for other countries. It turned out that the neo-liberal model of economic organization did not work in Scandinavian countries such as Denmark and Sweden because they embraced a qualitatively higher level, which suggested acting in well-developed market environments, policies and practices.

Developed economies have long believed that planning is a necessary evil, and now, they seek options to obtain proper control over the free market. From this point of view, one could, in fact, regard the liberalized market as a step backward from the level of current economic development. This is because neo-liberalism stands for the release of spontaneous market forces as a core value rather than the protection of public interest. In fact, critics of the neo-liberal nature could be found far before its official origin. The worldfamous physicist A. Einstein said back in 1949: "Unlimited competition leads to a huge waste of labor and to that crippling of the social consciousness of individual".

What, then, stimulated Bulgaria to undertake this step towards the implementation of neo-liberal ideology in the early 1990s? What forces led to the unconditional acceptance of these ideas in Bulgaria, which, like the other countries of Central and Eastern Europe (CEE), had been stuck until then in the radically opposite economic doctrine of central planning?

It was in 1989 that the idea of the central planning of economic activity totally collapsed in the socialist system in CEE, including Bulgaria. These countries undertook a transformation that was strongly influenced by the neo-liberal approach. Back in the 1990s, the neo-liberal idea easily found increasingly vigorous supporters, just because a new system was needed to replace the already denied central planning (or, as it was known, the administrative command system). Private ownership was recognized as the only plausible basis for economic life because it promoted a driving motive of profit and competitive markets. At that time, the Asian countries, particularly China (also employing a centrally planned economy at that time), emerged as important players in the global economic scene. Technological revolution, in full swing at that time, was exclusively stimulated by the creation of 
the global network, which brought about an array of innovation in the financial mechanisms. More visible, and also an unprecedented phenomenon from that time, was the 'demystification' of money (after the collapse of the Bretton Woods international monetary system in the early 1970s). Countries worldwide started using pure paper money without any correlation to gold or other measures of value; that change had significant implications upon financial and economic life. These events influenced the rise of neo-liberal ideas in the world, and most naturally, the same ideas have been selected as the building base in the process of transforming the countries with central planning to a market type economy.

Bulgaria was one of these post-communist countries that adopted an entirely new economic course toward the implementation of the neo-liberal concept after 1989. Perhaps the real problem of the Bulgarian economy and the problem for some of the other CEE countries was that the governments from that time had been making, as a rule, unfavorable decisions from strategic point of view. Thus, the overall effect of the so-called transition now could be regarded as negative in many aspects. It is still early to make such a definitive conclusion, even though it has been over two decades from the start of transformation (Innes, 2014; Kornai, 2006). It has to be taken into account that many benefits could not be possible to achieve in other way (such as free entrepreneurship and the equal treatment of different forms of ownership). On the other hand, the Bulgarian society from that time was definitely ill prepared to fulfill the needs of the process of establishing a fully free market. In the dawn of the transition, there was a total misunderstanding of the market principles not only in Bulgaria but more or less in the other CEE countries, which led to their altered implementation.

The foundation principle in the transition to a market economy is the change of ownership of the dominant state in central planning to private one. The bank's role is primarily directed toward the credit process. Therefore, the development of the banking sector in Bulgaria occupies a primary place in the economic and socio-political processes in the country in the years after 1989. It reflects both the essential processes of transition and its specificity for the country's own, including a number of deformations accompanying this transition.

The article attempts to consider the application of neo-liberal policies in the case of the Bulgarian bank- ing system reforms during the transition period from a centrally planned to a market type economy. To stress the huge difference between the two economic systems, the specificity and development of the banking sector are analyzed before and after the transition to a market type economy, i.e., during the 1980s and from 1989 onward. Following the reform of the banking sector up to the time of the world financial and economic crisis in 2008-2009, the negative effects of the liberalization of Bulgarian banking system are specified.

\section{The Bulgarian socialist banking sector legacy}

Under the conditions of central planning (up to 1981), the Bulgarian banking system consisted of a handful of state banks, including the Bulgarian National Bank (BNB) as the Central Bank, which combined the functions of issuing and commercial banks; the State Savings Bank (DSK), serving primarily the savings and credit activities of the population; and the Bulgarian Foreign Trade Bank, which specialized in foreign trade operations and the management of foreign reserves. In 1981 was founded Mineralbank (transformed in 1982 to Bank for Economic Initiatives - BSI). In 1986 and 1987, seven new commercial banks specializing in serving the industry structures were created. Thus, the first stage of banking reform was launched in Bulgaria. The new banks (called "associations") were established as joint stock companies; each of them specialized in lending to specific sectors, such as electronics and metallurgy. Although these companies were classified as commercial banks, they were rather like development banks because they granted loans only for long-term investment projects.

The activities performed by BNB were similar to those of a regular commercial bank, including the delivery of credit to businesses. The structure of mediation between savers and borrowers was extremely cumbersome. The majority of savings was gathered through the branches of DSK. From there, they were transferred to BNB.

At the end of 1989 and in 1990, the second stage of reform was launched by the conversion of 59 branches of the BNB into commercial banks, some of them with little capital (in large and/or industrial cities throughout Bulgaria). They have been transformed into commercial banks as joint-stock companies, some of them with little capital, and the BNB assigned the lending activi- 
ties completely to them. Changes have been made in the statutes of the banks to allow the inclusion of private equity. Shares are sold at face value, based on the carrying amount of the authorized capital of the bank on the date of their creation, although the real value was significantly higher. This act initiated the beginning of the transformation of the National Bank into an institution with functions typical of the western central banks. A substantial change in the National Bank status was carried out as it became more independent from the government and political influence. BNB was no longer subject to supervision by the Council of Ministers. It became responsible directly to the Parliament.

The transition to the market economy (1989 and onwards) imposed substantial structural changes in the banking system, primarily focused upon the destruction of state ownership and the accreditation of the private one (Campos \& Fabrizio, 2012). Furthermore, it is aimed toward the creation of a system in which the allocation of funds to the commercial banks and the pricing of assets and liabilities were to be carried out on a market basis. In the field of the financial sector, Bulgaria had to do the following operations to:

- encourage and promote the establishment of new financial instruments as an urgent decision of the system extra liquidity;

- promote the creation of a securities market and its instruments;

- develop the market pricing of capital;

- inspire the establishment of new private banks and financial institutions;

- encourage them to invest in pension funds and in financial assets in general.

The automation of payment and transaction systems and the development of the banking services and capital markets was also needed to facilitate the free trade of goods and services and financial transactions between economic agents.

\section{The first phase of transformation to a market type economy (1990-1996)}

It could be stated that the starting conditions for the economic reform in Bulgaria were at best unfavorable. The structural distortions were from the very beginning larger than in the other CEE countries because Bulgaria had an overly centralized governance system with al- most an entirely state-owned property of assets (nearly $95 \%$ ), an overly concentrated production structure, relatively low competitiveness of the local goods in foreign markets, an irrational employment structure, and a considerable budget deficit (-4.9\% of GDP in 1990). The Bulgarian gross external debt in 1989 was 52.5\% of GDP, which was regarded as unacceptably high and provoked the government's moratorium on creditors' repayment. For the sake of comparisons, in the end of $2013 \mathrm{H} 1$, despite the very restrictive fiscal policy of the Minister of Finance Simeon Diankov (2009-2013), who was a strong adherent to the neo-liberal policy, the gross external debt reached 95\% of GDP. This time, however, it was not considered as huge. The aforementioned initial conditions had a major negative effect on reforms and policies and led to a poor transition progress, particularly in the first half of the 1990s (Fries et al., 2006).

In line with the prime of world economics, at that time, neo-liberal ideas were noted as a natural choice to be followed by the emerging market economies in CEE. Any reluctance or suggestion of other ideas was regarded as a sign of backwardness and a hidden will to keep the status quo of the former socialist reality. The International Monetary Fund (IMF) and the World Bank undertook an active part in the CEE transition to a market economy (Wilczyński, 2011). Their main objective was to discredit the Keynesian model of directed or managed economic policy by the Government and to impose the neo-liberal model of Milton Friedman and the related Chicago School of Economics. The two international organizations encouraged leaders of economically and financially unstable countries to implement a series of economic and social reforms so that communism would be no more. Dozens of countries, not only in the CEE but all over the world, followed the Stabilization and Structural Adjustment Programs of the IMF. The results, however, were far from satisfactory. Among the most recommended were the projects with an allegedly positive effect on GDP growth. Then, the US Agency for International Development (USAID) and the international banks offered "preferential" loans bearing strictly restrictions. By acting as economic consultants in these countries, they and their experts worked out long-run forecasts. Some of the names of the economic consultants in the CEE countries are well known. The "shock therapy" in Poland was organized under the program of Jeffrey 
Sachs, who was a young Harvard graduate at that time. For Russia, the name of this consultant was Noreena Hertz, a British economist from the World Bank.

The initial stage of reforms, the basis of the Bulgarian "neo-liberal project" was settled according to the so-called "RahnUtt Plan" (Rahn \& Utt, 1990). The Plan set out the main points of the transition to a market economy, in particular the preparation of a privatization program, monetary reform, the free exchange of foreign currencies, the elimination of controls over wages and prices, fiscal reform, commercial law, and the establishment of social policy. This Plan was developed by Prof. Richard Rahn, the chief economist of the US Chamber of Commerce, and his colleague Ronald Utt along with two teams of economic advisors: American and Bulgarian. Drafted from March to August 1990 and accepted by the Grand National Assembly, that Plan outlined the transition of the Bulgarian economy from governmental socialism to neo-liberalism.

The official start of the economic reform in Bulgaria is the $1^{\text {st }}$ of February 1991. It was ambitious, including comprehensive prices, trades and foreign exchange liberalization, the restitution of land and urban property, and the privatization and de-monopolization of specific segments of the large enterprise sector. By radical economic reforms, we refer to the privatization of the stateowned enterprises in Bulgaria, which were envisaged to be only market oriented in contrast to the practice in other emerging market economies, such as Russia or the Czech Republic and Slovakia, where privatization had a stronger social orientation (Miller \& Petranov, 2000). Concerning land reform, the Land Law required that restitution of property had to be done within the real boundaries of land owned in 1946. This process of land restitution was very complicated and was accompanied by frequent amendments in the Law (35 times within the period 1991-1999), and it lasted nearly ten years.

Stabilization policies were initially successful with respect to the budget deficit and inflation. The newly created environment for private small business fostered the establishment of new private firms, primarily in trade and services. Debt reduction agreements improved to a certain extent Bulgarian external debt situation, but it was still insufficient to ensure economic recovery. The GDP declined for five consecutive years. It was not until 1994 that the growth was restored, but it was for only two years; in 1996, the GDP dropped again by over $10 \%$ in comparison to 1995 . The relatively improved economic performance in 1994 and 1995 was due to the efforts of the ruling socialist party government to slow the process of the collapse. The cumulative decline in output of over $30 \%$ was followed by a rapid increase in unemployment (Table 1).

Table 1. Bulgaria: Main Macroeconomic Indicators (in \%), 1990-1995.

\begin{tabular}{lcccccc}
\hline INDICATORS & $\mathbf{1 9 9 0}$ & $\mathbf{1 9 9 1}$ & $\mathbf{1 9 9 2}$ & $\mathbf{1 9 9 3}$ & $\mathbf{1 9 9 4}$ & $\mathbf{1 9 9 5}$ \\
\hline Real GDP (growth rates) & -9.1 & -11.7 & -7.3 & -2.4 & 1.8 & 2.5 \\
Real wages (growth rates) & 5.3 & -39.1 & 14.9 & 1.4 & -20.5 & -7.5 \\
Consumer price index (growth rates) & 23.8 & 338.5 & 79.4 & 56.1 & 87.1 & 62.2 \\
Employment (growth rates) & -6.1 & -13.0 & -8.1 & -1.6 & -2.0 & -2.4 \\
Unemployment rate & 1.7 & 11.1 & 15.3 & 16.4 & 12.8 & 11.1 \\
Real industrial output (growth rates) & -16.8 & -22.2 & -15.9 & -10.9 & 8.5 & 4.9 \\
Real personal consumption (growth rates) & -3.3 & -15.7 & 1.0 & -0.7 & -2.6 & - \\
Budget deficit (share of GDP) & -4.9 & -3.8 & -5.7 & -11.5 & -6.6 & 6.7 \\
Real money (M1; growth rates) & 5.8 & -48.4 & -21.6 & -18.2 & -4.6 & 5.5 \\
\hline
\end{tabular}

Note: Adapted from "Main Macroeconomic Indicators, 2007," by National Statistical Institute (2014). Retrieved from http:// www.nsi.bg/otrasal-publikaciaen.php?n=156\&otr=42 
Perhaps one of the main weaknesses of neo-liberal policy was the assumption that the mere placement of the economy to a market basis would lead to its automatic optimization and efficiency improvement. Bulgarian (and not only Bulgarian) practice has shown that this is far from being the whole truth. During the adaptation period (which, in principle, could last for decades), states are virtually defenseless. This situation could be summarized by the words of the president and founder of Intel Corporation, Andy Grove (Palast, 2004, p. 98): "The purpose of new capitalism is to shoot the wounded". The contemporary experience has shown that in addition to the deprivation of the defense mechanisms, the emerging market economies, including Bulgaria could not rely on the adequate protection of international institutions because the voices there belong to the developed economies, which have neither the interest nor the capacity to protect the weaker ones.

\section{Privatization of the banking sector}

In the early 1990s, BNB was a possessor of 59 banks. It had control in all of them, and the remaining shares were held by primarily state-owned companies. In this manner, the ultimate owner of all the Bulgarian banks was the state.

The banking sector liberalization had been initiated in the beginning of 1990s on a congress of the Union for Private Economic Enterprise (SSIG), which made the resolution of the private bank establishment. The founders of SSIG offered to the former party chairman of the United Democratic Forces (and, a few months later, the president of the country) Zhelju Zhelev to submit a proposal of the abolition of the state monopoly on the banks for a discussion in Parliament. A few days later, Parliament accepted an amendment of the Constitution art. 13, thus providing a gradual withdraw of BNB from the position of a major shareholder through a sale of its shares.

It was expected that the privatization of the sector and the liberalization of the financial services market would lead to an improvement of market efficiency and that the eight specialized banks eventually would merge with some of the 59 commercial banks. As a result, the country would get an advanced system of money supply and run entirely on a market basis. Initially, the plan was successful. There was a real "license blast". In 1997, the number of banks in Bulgaria reached 87 , which was the largest number in comparison with the other former socialist countries. The number of banks was several times larger than in Hungary, Czech Republic, and Poland (Wagner, 2000). In a short time, the count of private banks grew exponentially, but in almost all cases, the resource of equity capital and the purchase of shares were provided by loans from state banks and DSK. From 1990-1995, the DSK granted BGN 70 billion loans and the majority of them were used for that purpose. Hundreds of brokerage houses, exchange bureaus and other financial entities received licenses. Thus, a parallel banking system began to operate in the country.

The lack of regulations was felt not only in the licensing process. In 1990-1991, huge loans were granted without proper collateral (unrecoverable by definition). In fact, the accumulated resource in Bulgarian banks was donated in the form of credit with no idea of its further return to the vaults. In the short period until 1997, the functions of local banks actually degraded to a simple appropriation of society's assets and their further donation to the domestic oligarchs. It should be noted that the main factor that allows this process to happen was actually the lack of adequate regulations.

One could summarize that the withdrawal of the state as an institution contributes not to an increase in financial system efficiency but rather to its destruction. Even after the establishment of legislation, there were so many doors left open in the newly created laws, and the control over their observance was so weak that it was as if they did not exist at all (Minassian, 2013).

Comparing the banking system performance before and after 1997, one could state that at the beginning of the crisis, the private banks were owned by domestic entrepreneurs, and thus, the banking sector was far from any views and standards of the modern banking. The process of bank creation (and not only bank creation) was poorly supervised. Banks' emerging process allowed the assets of a given bank to be used for establishment of another one. It resulted in a number of hollow banks and in the distribution of their loan portfolio between unreliable borrowers. The lending was also poorly controlled. In addition, the Bulgarian population did not display market behavior and thus facilitated the bank or other financial organizations' owners. Before the following crisis in 1996-1997, the 

To summarize: The reasons for the negatives, including the very slow recovery and poor economic growth in Bulgaria up to 1997, could be seen as three main factors: (a) inadequate initial conditions for a country with strong central planning to transition to a market type economy in combination with poor economic performance; (b) the adoption of overly radical reforms in all sectors of this economy and their inconsistent implementation; and (c) economic mismanagement. It is hard to favor any of these factors. An equally important role for this crisis was the premature withdrawal of the state from the banking sector along with purely domestic political factors. Bulgaria had an unfavorable combination of neo-liberal views and a specific political environment of dominating influence of the socialist party in an ideological struggle with the opponents, who called themselves democrats and embraced the neo-liberal policy to the letter. In this respect, the frequent change of governments was very indicative. Within seven years (1990-1997), the country went through a line of seven governments of different parties, each of them applying the formula for a political cycle in a very condensed version (because nobody was aware of the duration of their term). Thus, the newly emerging Bulgarian market environment became a combination of the worst aspects of two opposing ideologies, and it allowed the obvious weaknesses of neo-liberalism to be exposed. Conditions in Bulgaria were extremely inappropriate for its implementation because it presupposes the existence of a developed market environment, practices and attitudes that did not exist in the country. Under the slogan of banking sector liberalization, the corruption was widely spread, and the society savings were redistributed in the form of unsecured loans.

The changing philosophy of the reform implemented by different governments over time along with the slow, inconsistent structural reforms impeded the achievements of macroeconomic stabilization. Seven years after the start of the transition, the Bulgarian economy was still in a crucial situation with restricted foreign financing, depressed employment and low investment activity. The lack of structural reforms began to show harmful repercussions on the monetary reform and economic stabilization as a whole. Combined with real currency depreciation, the lack of structural reforms led to the weakening balance of payments and to a decline in foreign reserves. In addition, the impending external debt service obligation enforced an exchange rate crisis. The banking system collapsed. Both high inflation and large exchange rate movements undermined the credibility in economic management.

The reform of the banking sector was not in accordance with transformations in the real (non-financial) sector. This discrepancy had a significant influence on the function of the entire banking sector, and it gradually became a factor that had an adverse effect on the national economy.

This crisis had lasting effects on the banking sector, including the deregulation of the financial sector through the rejection of monetary policy and the introduction of the currency board, the devaluation of debt and the loss of the savings due to hyperinflation. The annual average CPI for the previous year $=100$ was $121.6 \%$ in 1996 and $1058.4 \%$ in 1997; afterwards, it sharply slowed down. As a result, the population lost nearly $70 \%$ of its savings, impaired assets were intensely redistributed, and the citizens were impoverished, and so on.

Huge losses of the public sector logically led to private sector capitalization. This process generally created opportunities for significant investment in the real sector, but a significant portion of the amount received at that time was used for personal consumption in the private sector, taken out of the country or invested in real estates and financial transactions abroad.

Economists today are convinced that the failure in 1996 of 16 banks completed the first phase of capital accumulation in the country. Then, missing money was invested in the secondary distribution of capital in the privatization. In practice, assets of USD 35 billion were appropriated. Thus, oligarchs and the richest $1 \%$ people from the total population were born.

\subsection{The second phase of the transformation to a market type economy (1997-2008)}

Political and economic changes in the first half of 1997 aimed to stabilize the economy and to restore confidence. The program agreed with the IMF entailed introduction of a currency board regime (from 1 July 1997), price liberalization, and a major acceleration of privatization. In general, the program placed a strong emphasis on structural reforms. 
Table 2. Bulgaria: Main Macroeconomic Indicators (in \%), 2004-2013

\begin{tabular}{lcccccccccc}
\hline & $\mathbf{2 0 0 4}$ & $\mathbf{2 0 0 5}$ & $\mathbf{2 0 0 6}$ & $\mathbf{2 0 0 7}$ & $\mathbf{2 0 0 8}$ & $\mathbf{2 0 0 9}$ & $\mathbf{2 0 1 0}$ & $\mathbf{2 0 1 1}$ & $\mathbf{2 0 1 2}$ & $\mathbf{2 0 1 3}$ \\
\hline Growth of real GDP a & 6.7 & 6.4 & 6.5 & 6.4 & 6.2 & -5.5 & 0.4 & 1.8 & 0.6 & $0.9^{\circ}$ \\
Inflation $^{\text {b }}$ & 6.1 & 5.0 & 7.3 & 8.4 & 12.3 & 2.8 & 2.4 & 4.2 & 3.0 & 0.9 \\
Unemployment & 12.0 & 10.1 & 9.0 & 6.9 & 5.6 & 6.8 & 10.2 & 11.3 & 12.3 & 12.9 \\
Cash deficit/surplus, \% of GDP c & 1.7 & 3.1 & 3.4 & 3.3 & 2.9 & 0.9 & -4.0 & -2.0 & -0.5 & -1.8 \\
Current account balance, \% of GDP & -14.0 & -11.6 & -17.7 & -27.2 & 22.9 & -8.9 & -1.5 & 0.1 & -0.8 & 1.9 \\
State debt (Maastricht), \% of GDP & 37.8 & 28.9 & 22.4 & 17.9 & 14.2 & 14.6 & 16.2 & 16.3 & 18.4 & 18.9 \\
\hline
\end{tabular}

Note: Adapted from "Main Macroeconomic Indicators, 2007," by National Statistical Institute (2014). Retrieved from http:// www.nsi.bg/otrasal-publikaciaen.php?n=156\&otr=42

a previous year $=100$

${ }^{\mathrm{b}}$ annual average $\mathrm{CPI}$, pervious year $=100$

c unemployment rates of population aged 15 years and over

As a result of adequate policies, although under very difficult conditions, Bulgaria achieved relatively good economic performance in the last four years leading up to 2008 (Table 2). The functioning currency board contributed positive results in the monetary stabilization and adjustment to a process of disinflation and fiscal consolidation. As the IMF reported, the fiscal tightening helped to curb the current account deficit to a level that could be strictly implemented (Aristovnik, 2007), serving to retain labor costs and maintain competitiveness. Structural reforms continued on a wide front: Privatization and enterprise restructuring were accelerated, land restitution was completed, and trade and price liberalization continued (see IMF Staff Country Report, April 2000). In the beginning of 2001, the private sector had already been producing nearly $70 \%$ of the gross value added and over $60 \%$ of GDP.

From 1997-2001, the government gave a sound commitment to the integration of Bulgaria with the EU structures. It followed a strong Eurodirected strategy. As a result, a budget surplus was achieved in 1998 and 1999, the public debt as a percentage of GDP decreased along with interest rates (Epstein \& Jacoby, 2014). All these factors along with the fixed exchange ratio of the national currency brought Bulgaria closer to the requirements for participation in the European Monetary Union (EMU).
The period from 1 July 1997 onward, in the conditions of the currency board arrangements, marks the banking system stabilization. However, its further liberalization continued with the invasion of foreign capital in Bulgarian banks (combined with the inadequate control of the financial intermediation system). A number of banks went bankrupt, and others were merged, thus reducing the number of the banks to 17 , the majority of which were foreign. The main effect was initially positive. The foreign investments brought know-how, improved the Bulgarian banks capital adequacy and thus returned the confidence in the system. In a relatively short time (only 3-4 years), the sector has turned to a normal functioning. Because of the implementation of the currency board, however, the state actually gave up its regulating capabilities, and the system was left on its own. The effect of this policy was very noticeable, particularly after 2005, when the credit (and the consumption of imported goods) raised rapidly despite the central bank's attempts to cool down the expansion.

The negative influence of this process soon became apparent. The commercial bank's strategy was focused mostly upon the expansion within the households and the sectors with a quick return, which led to a sharp decrease in the country's competitiveness. It was a logical consequence of the prioritized financing of hotels, restaurants and services on the count of stra- 
tegic branches with some longer return terms. The last ones could not cover the raised interest costs, and that is why they were left without funding. As a result, the structure of production in the country degenerated (Sariiski \& Rangelova, 2013). Bulgaria now produces and ships abroad primarily products with lower value added, which led to a profit decline and hence to further economic deterioration. The second problem was that the credit expansion stimulated a rapid growth of individual consumption in Bulgaria (Sariiski, 2010). This led, on the one hand, to an imports increase (on the count of local goods consumption) and, on the other, to an increase in the living standard and wages of employees. For this reason, the process of relocation that was going until then and supporting at least to some extent the economic development had quickly collapsed.

Furthermore, the negative influence of the intensive banking sector liberalization became apparent later in 2008, when Bulgaria felt the first effects of the global financial crisis. Currently, Bulgaria is one of the five European countries with highest share of bad loans (NPL). Unfortunately, the losses in one way or another are being now absorbed and passed on to the regular banking system consumers, i.e., the population and business (Sariiski, 2011).

The negative consequences of the transition to a market economy had a stimulating effect on the lending in Bulgaria, although it may seem paradoxical. Seizing the savings of the population during the first stage of the transition to 1997 and the loss of jobs due to the closure of state-owned enterprises brought about an unemployment rate of $18 \%$ in 2001 . The latter, combined with the pumping of the added value by the use of illegal practices (such as the privatization of the input and output of the economic activity) led to the concentration of wealth and economic power in a limited group of individuals with excessively high incomes and consequently to a rapid impoverishment of the rest of the people. Those individuals became unable to compensate for the contraction of income in ways other than the increase of debt. J. Stiglitz (2009) summarizes this very well: "Increasing inequality means a transfer of money and assets from those at the bottom who can spend it to those at the top who can't. To the people at the bottom we saying that they should continue spending and we continue to lend to them." In a normal economic situation, the purchasing power parity decline would lead to a crisis of overproduction and offset the reduced income (albeit at the expense of an increase in debt), which, in turn, would lead to its revival. In Bulgaria, however, the principle was different because most of the production facilities were liquidated in the first phase of transition. That is why the lending stimulated just the import of consumer goods.

Thus, the status quo of the new economic structure was reinforced (Sonin, 2013). Preferences gradually, yet steadily, turned towards the import production; the qualification of employees in the manufacturing sector became permanently lost. The regenerative capacity of the real sector declined. For the banking system, negative consequences of this process occurred a few years later. It is well known that the banking sector could function independently of its foundation, which was the real sector, but the latter was progressively left without the necessary funding. During the period 1999-2006, the share of corporate loans gradually decreased from $81 \%$ to less than $60 \%$. A significant stimulating role upon the loans demand at the later stage of transition was played by the expectations that resulted from the forthcoming accession of Bulgaria in the European Union (EU). According to a survey in 2010 on households' budgets, a considerable portion of Bulgarians suffered a permanent deficit (Sariiski, 2010). For more than half of the respondents, the total of debt servicing and the cost of vital minimum provisions (including, e.g., costs for food, utilities, and the provision of housing) are close to $100 \%$ or even higher, i.e., part of these budgets maintain a permanent deficit. For this reason, the regular servicing of loans for more than $70 \%$ of the respondents is problematic, which reflects the deterioration of the commercial banks' loan portfolio and the contraction of the retail segment.

In fact, the increase in retail lending during the late phase of the transition until the beginning of the global crisis (2008-2009) was fully at the expense of the shrinking of corporate loans' share. What further aggravated the economic potential was the issuance of the bulk of loans to ventures that could not contribute to long-term economic growth (Sariiski \& Rangelova, 2013). During the period 2005-2008, quick return was the main priority of financial intermediaries in the 

The problem was that other than the banks, no other industry would function well in the country because of the decapitalization process that led to the liquidation of enterprises, the loss of jobs and so on. More serious was the problem of the liquidation of the deterioration of intangible assets, such as primary human capital and confidence in the system. The government institutions have in every way demonstrated that they cannot be a reliable partner in the social contract. A typical example is the dysfunctional health care system, which employs a unilateral obligation to supply funds for health care but without the reciprocal commitment of the state to ensure the specific health status of the population. This reflects very negatively on the banking system as it strengthens the savings motive of the population; this, in turn, deprives the local economy of the recovery potential.

For this reason, the restoration of Bulgarian business depends entirely on the foreign markets' recovery (Jacoby, 2014). Bulgarian business agents are not willing to invest in the activities expansion, adopting a passive attitude in the lending activity. Data for 2013 show that bank loans are maintaining a constant level. The Bulgarian banks succeeded only to compensate their loan portfolios' depreciation, but the overall volume and structures remain unchanged. It should be noted that the totals include a few banks with growth ratios exceeding $30 \%$, i.e., if one excludes such banks from the statistics, the lending actually shrinks.

\section{Effect of the world financial crisis of 2008-2009 on the banking sector in Bulgaria}

In the period preceding the financial and economic crisis in 2008-2009, a new accumulation of negatives in the banking sector was observed. Commercial banks granted credit to increasingly less reliable customers for the sake of the gain of the market share (Almunia et al, 2010; Erdinç, 2010). The Bulgarian National Bank was unable to control this process because the currency board was strongly limiting its capacity to influence the money supply. Despite several attempts, the Bulgarian National Bank did not succeed in controlling the banks' expansion (Sariiski, 2011). As a result, Bulgaria achieved the fastest pace of lending in the region of CEE during the period 2006-2008. However, it "mined" the sector in the name of winning the market share; the banks gradually lowered their criteria of reliability. The loans from this period are the main reason for the losses from deteriorated exposures. A large portion of the loans past due over 90 days were granted during the period 2005-2007.

Another, even more serious problem of the banking sector was the missing potential for its recovery. The status to which the economy was brought as a result of the transition processes led to a weak realization of financial products. Local businesses are functioning at low profitability rates, and the main part of the value added is created in sectors recovering particularly slowly by definition (such as tourism and real estate). Furthermore, the weak domestic market does not encourage the manufacturing recovery, and it continues to be reflected in the reduction of the business cash flows and difficulties in debt servicing. In addition, strict fiscal discipline contributes to the deterioration of the economic and social environment; the implementation of a restrictive policy to maintain a balanced budget in times of crisis caused by limited demand is not the right approach (Petkov, 2014).

The prevailing attitude of both investors and consumers still remains passive, and this is largely due to a sense of insecurity among economic agents. Throughout the transition period in Bulgaria, the state institutions have repeatedly demonstrated that they lack the capacity to provide a stable environment, and the general direction of their actions is pointed to their withdrawal from economic life.

The state would not commit to any warranties of providing living, educational and health minimums to protect property rights or to implement long-term strategies. The private interests of public officials (or sometimes the absence of interests) lead to a delay of specific measures that would help not only the banking sector but the entire economy, such as the construction of e-government and the access to property registry.

Therefore, the situation at the time actually blocks the money transmission. The insurance motive encourages people to increase their savings. The financial intermediaries, however, are unable to realize cumulated resources because business is not willing to undertake new ventures. Everyone would find themselves losing in this situation because the market was left long enough to itself. 


\section{Conclusions: Summarizing the negative effects of neo-liberal policies on the Bulgarian financing sector}

The failure of neo-liberalism can be summarized in the following way:

First, neo-liberal policy distorts the very idea of a free market because having a monopoly upon the key resources and zero regulation of (in fact) quasi-market practices could not be connected with liberalism; this environment favors development of incorrect and most importantly unproductive practices.

Second, the very focus of neo-liberal ideas, which defend the release of all marketing elements and processes with zero planning, is wrong because it is essentially a return to a stage of development before the emergence of modern society. It should be noted that an entirely unrestricted and unregulated flow of processes are traits of the wilderness.

Third, neo-liberalism creates conditions for state institutions "to play on both sides of the street." If one has to stick tightly to neo-liberal ideas, the state should be engaged primarily with the guarantees of the free market's normal functioning and not interfere in business. Practically, however, the state authorities constantly interfere in the functioning of markets by protecting certain specific private interests. The state officially does not obtrude in the free markets, but it unofficially supports its favorites in various ways, e.g., the direction of the state orders to specific enterprises, timely VAT reimbursement, and excessively close cooperation with selected partners that borders on inappropriate.

The development of the banking sector in Bulgaria in the transition to a market economy shows certain negative effects on the Bulgarian banking sector and the economy as a whole. These effects can be formulated, as follows:

- The first negative effect of neo-liberal policy is the exportation of ownership (and control) upon banking system assets. The most profitable business of utmost importance to the economic development was given to foreign investors, who can now carry out their own policy and, moreover, operate on behalf of others, for instance, on the count of interestfree financing by the European Central Bank.

- The second negative effect is the bringing of the banking system to a condition in which it is dereg- ulated in a position of "self-defense". Introduction of the currency board in 1997 fixed the local currency to the German mark and since the emerging new currency in 1999 to Euro, which, on the one hand, contradicts the exporter's interest, and on the other hand, restricts the regulator and strongly limits its capacity to manage the stability of money supply.

- The third negative effect is the placement of the banking sector before 1997 into the role of mediator in totally unfavorable assets redistribution and the emergence of the local oligarchy. During hyperinflation, household savings were transferred to the so-called credit millionaires. This led to the exhaustion of confidence in the local banking institutions and to their isolation from the economic turnover. It should be noted that for a long time, the transactions in Bulgaria were settled in cash rather than by bank transfer.

- The fourth negative effect concerns the real economy agents as the bank's clients. It is known that the banking sector gains profits primarily from the real economy; however, Bulgaria's case is different. The "regular" companies have low profitability indicators; the majority of the value added is derived from monopolies. Similar is the situation with regular customers, i.e. households and individuals. Although some stabilization of income is formally reported, their personal perception is still about impoverishment and increasing difficulties in loans servicing.

- The fifth negative effect is the elimination of prospects for the long-term growth of the banking sector due to the passive attitude of the state power, which still remains isolated from the banks. Its main tool of management and interference in lending is the Bulgarian Development Bank, but it is more often used to serve private interests rather than for the conduction of a state policy aimed to encourage the financing of strategic projects. The government could use fiscal measures such as tax relief on interest rates for lending to certain sectors, but it fails to do so because it contradicts the neoliberal idea of non-intervention.

- The sixth negative effect results from the weak protection of the taxpayers. The protection of small savers provided from the State Fund for Deposit In- 
surance is not reliable because resources in the fund are limited, and their use is regulated in a wishful style. This can lead to a rapid outflow of deposits at the first signs of instability and hence to a liquidity crisis.

- The seventh negative effect is entirely on the count of commercial bank owners. Neoliberal ideas of aggravation of the internal competition determine the mandate thinking in managers, including the maintenance of current profits at the expense of future development prospects. The aftermath of this style of thinking was manifested clearly in the beginning of the last financial crisis of 20082009.

In summarizing, the transition period has effectively led to the establishment of a modern banking system in the country, but this system serves only the accumulation of profit (almost all of it belonging to the foreign investors) and does not promote the processes of recovery and growth.

\section{References:}

Almunia, M., Bénétrix, A. S., Eichengreen, B. J., O’Rourke K. H., \& Rua, G. (2010). From great depression to great credit crisis: similarities, differences and lessons. Economic Policy, 25 (62), 219-265.

Amable B. (2010). A change of model requires a new balance of power. In A. Watt \& A. Botsch (Eds.), After the crisis: towards a sustainable growth model (pp. 151-153). Brussels: European Trade Union Institute.

Aristovnik, A. (2007). Are current account deficits in Eastern Europe and former Soviet Union too high? Transformations in business \& economics, $6(1), 32-52$.

Bebchuk, L. A., Fried, J. M. (2004). Pay without performance: The unfulfilled promise of executive compensation. Cambridge, MA: Harvard University Press.

Bank Octopus hidden in the secret report "Dobrev" [Банков октопод скрит в секретния доклад „Добрев”] (2010, April 9). [Online forum comment]. Retrieved from: http://frognews.bg/ news_22026/Bankov_oktopod_skrit_v_sekretniia_doklad_Dobrev/
Bogle, J. C. (2005). The executive compensation system is broken. Journal of Corporation Law, 30 (4), 761-765.

Campos, N. F., Coricelli, F. (2012). Financial liberalization and reversals: political and economic determinants. Economic Policy, 27 (71), 483-513.

Einstein, A. (1949). Why socialism? Monthly Review, 1 (1), 9-15.

Epstein, R. A. \& Jacoby, W. (2014). Eastern Enlargement Ten Years On: Transcending the East-West Divide. JCMS: Journal of Common Market Studies, 52 (1), 1-16.

Erdinç, D. (2010). Does a credit boom increase bank fragility? Eastern European Economics, 48 (3), 68-87.

Fries, S., Neven, D., Seabright, P., \& Taci, A. (2006). Market entry, privatization and bank performance in transition. Economics of Transition, 14 (4), 579-610.

Greespan, A. (2008, October 23). Greenspan destroys deregulation in 16 seconds [Video file]. Retrieved from https://www.youtube.com/watch?v=bAHo7oEiyY

Innes, A. (2014).The Political Economy of State Capture in Central Europe. Journal of Common Market Studies, 52 (1), 88-104.

Jacoby, W. (2014). The EU Factor in Fat Times and in Lean: Did the EU Amplify the Boom and Soften the Bust? Journal of Common Market Studies, 52 (1), 52-70.

Kaletsky, A. (2010). Capitalism 4.0: The birth of a New Economy. London, UK: Bloomsbury Paperbacks.

Kornai, J. (2006). The great transformation of Central Eastern Europe. Economics of Transition, 14 (2), 207-244

Lacqua, F., \& O’Donnell, S. (2009, January 29). Taleb says: Nationalize banks, you can't trust them [Press release]. Retrieved from http://www.bloomberg. com/apps/news? pid=newsarchive \&sid=asvQUP gW.EZY

Miller, J. B., \& Petranov, S. (2000). The first wave of mass privatization in Bulgaria and its immediate aftermath. Economics of Transition, 8 (1), 225-250.

Marangos, J. (2009), The evolution of the term 'Washington Consensus', Journal of Economic Surveys, 23 (2), 350-384. 
Minassian, G. (2013). Bulgarian banking: looking for sustainability. Contemporary Economics, 7 (3), 95-114.

National Statistical Institute (2014). Main Macroeconomic Indicators, 2007. Retrieved from http://www. nsi.bg/otrasal-publikaciaen.php? $\mathrm{n}=156 \&$ otr $=42$

Palast, G. (2004). The Best Democracy Money Can Buy. New York, NY: Plume.

Palley, T. I. (2002). A new development paradigm domestic demand-led growth [Discussion paper, Foreign Policy in Focus project]. Retrieved from http:// www.thomaspalley.com/docs/articles/economic development/new_development_paradigm.pdf

Petkov, V. S. (2014). Advantages and disadvantages of fiscal discipline in Bulgaria in times of crisis. Contemporary Economics, 8 (1), 47-56.

Rahn, R. W., \& Utt, R. D. (1990). Paper on the Project on Economic Growth and Transition to a Market Economy in Bulgaria. USA National Chamber Foundation for Republic of Bulgaria, Washington, DC.

Sariiski, G., \& Rangelova, R. (2013). Development of the banking activity as an economic growth factor. In Post-crisis economic development in the EU and Bulgaria: Proceedings of the international conference, Economic Research Institute, Bulgarian Academy of Sciences (pp. 277-292). Sofia: GorexPress.

Sariiski, G. (2011). The Global Crisis - Origins and Impact on the Bulgarian Banking System. Sofia: Economic Policy Institute.

Sariiski, G. (2010). Problems of the Bulgarian households' indebtedness. In M. Trifonova (Ed.), Competitiveness of the Bulgarian economy: Proceedings of the IV Conference (pp. 51-63). Sofia: Economic Policy Institute.

Sonin, K. (2013). The end of economic transition. Economics of Transition, 21 (1), 1-10.

Stiglitz, J. (2010). Freefall: Free Markets and the Sinking of the Global Economy. New York, NY: W. W. Norton \& Company.

Stiglitz, J. (2009, March 17). Growing economic inequality lies at root of global crisis. Shanghai Daily. Retrieved from http://www.shanghaidaily.com/ Opinion/foreign-perspectives/Growing-economic-inequality-lies-at-root-of-global-crisis/shdaily. shtml
Wagner, H. (2000). Central Banking in Transition Countries, Eastern European Economics, 38 (4), 6-53.

Wilczyński, R. (2011). Global financial governance: a perspective from the International Monetary Fund. Contemporary Economics, 5 (1), 4-16. 
